\section{5-Deoxybostrycoidin, a New Metabolite Produced by the Fungus Nectria haematococca (Berk. and Br.) Wr.}

Denise Parisot*, Michel Devys**, and Michel Barbier**

* Laboratoire de Cryptogamie, Bâtiment 400, Faculté des Sciences, F-91405 Orsay, France

** Institut de Chimie des Substances Naturelles, CNRS, 91198 Gif sur Yvette Cedex, France

Z. Naturforsch. 44b, 1473-1474 (1989);

received July 10, 1989

5-Deoxybostrycoidin, Fungus,

Nectria haematococca, Pigments, Naphthoquinone

The structure $\mathbf{2}$ is established for 5-deoxybostrycoidin, a new metabolite isolated from cultures of the fungus Nectria haematococca (Berk. and Br.) Wr., on the basis of physico-chemical data (MS, ${ }^{1} \mathrm{H}$ and

${ }^{13} \mathrm{C}$ NMR, acetylation) and by reference to the known bostrycoidin $\mathbf{1}$.

In cultures the fungus Nectria haematococca (Berk. and Br.) Wr., produces a series of highly coloured naphthoquinones related to fusarubin. Fourteen of these substances were previously isolated among which eight were new [1]. Recent work [2] showed that the antibiotic bostrycoidin 1 resulted from the action of ammonia on anhydrofusarubin lactol 4. This last compound is the hemiacetal of fusarubin aldehyde and is thus immediately related to fusarubinoic acid [3], the likely precursor of fusarubin, javanicin and other naphthoquinones of the series.

For the production of the 5-deoxybostrycoidin 2, the 169 red mutant of Nectria haematococca [4] was grown at $26{ }^{\circ} \mathrm{C}$ in liquid still cultures. The medium consisted of glucose $22.5 \mathrm{~g}$, L-asparagine, $\mathrm{H}_{2} \mathrm{O}$ $9.5 \mathrm{~g}, \mathrm{KH}_{2} \mathrm{PO}_{4} 1 \mathrm{~g}, \mathrm{KCl} 0.75 \mathrm{~g}, \mathrm{MgSO}_{4}, 7 \mathrm{H}_{2} \mathrm{O} 0.5 \mathrm{~g}$, $\mathrm{CaCl}_{2}, 2 \mathrm{H}_{2} \mathrm{O} 0.15 \mathrm{~g}, \mathrm{FeSO}_{4}, 7 \mathrm{H}_{2} \mathrm{O} 0.003 \mathrm{~g}, \mathrm{ZnSO}_{4}$, $7 \mathrm{H}_{2} \mathrm{O} 0.003 \mathrm{~g}, \mathrm{CuSO}_{4}, 5 \mathrm{H}_{2} \mathrm{O} 0.00125 \mathrm{~g}, \mathrm{MnSO}_{4}$, $\mathrm{H}_{2} \mathrm{O} 0.00035 \mathrm{~g}, \mathrm{Na}_{2} \mathrm{MoO}_{4}, 2 \mathrm{H}_{2} \mathrm{O} 0.00025 \mathrm{~g}$, distilled water 1 liter ( $\mathrm{pH} 5.5)$. The growth of the fungus was initiated by inoculating $25 \mathrm{ml}$ of medium in Petri dishes with $100 \mu \mathrm{l}$ of a microconidial suspension $\left(10^{6}\right.$ spores per $\mathrm{ml}$ ). After $4-5$ days the medium became orange and the $\mathrm{pH}$ rose to $7.5-8$. The culture fluid was filtered, extracted first at $\mathrm{pH} 8$ with ethyl acetate

\footnotetext{
* Reprint requests to Dr. M. Barbier.

Verlag der Zeitschrift für Naturforschung, D-7400 Tübingen 0932-0776/89/1100-1473/\$ 01.00/0
}

till the extracts became pale yellow and then reextracted after acidification to $\mathrm{pH} 3$ with acetic acid. A red and a yellow major pigments were found in both extracts after $\mathrm{SiO}_{2}$ TLC in $\mathrm{CH}_{2} \mathrm{Cl}_{2}-\mathrm{MeOH}$ 99:1 (red product, bostrycoidin 1 , Rf 0.53 , yellow substance, 2, 5-deoxybostrycoidin, Rf 0.70 , while standard fusarubin had Rf 0.32 ). Preparative TLC's in the same conditions gave 45 and $6 \mathrm{mg}$ of these two substances per liter of culture filtrate of the 169 mutant of $N$. haematococca, respectively.

The red compound was identified as bostrycoidin 1 on the basis of MS, ${ }^{1} \mathrm{H}$ NMR, Rf, mp., by comparing with a standard of this product. The substance $\mathbf{2}$ was crystallized from $\mathrm{CH}_{2} \mathrm{Cl}_{2}$-hexane giving yellow needles, mp. $195-196{ }^{\circ} \mathrm{C}$, IR (KBr) 1680, 1635, $1590 \mathrm{~cm}^{-1}$, UV (MeOH) 207, 237, 270, 322 (sh.), $414 \mathrm{~nm}$, characteristic values for the 1,4-naphthoquinone moiety in 2 . The molecular formula $\mathrm{C}_{15} \mathrm{H}_{11} \mathrm{NO}_{4}$ was established by MS $\left(\mathrm{m} / z 269, \mathrm{M}^{+}\right)$and by elemental analysis: calc. C 66.91, H 4.12, N 5.20\%; found C $66.89, \mathrm{H} 4.32, \mathrm{~N} 4.93 \%$. The ${ }^{1} \mathrm{H} \mathrm{NMR}\left(\mathrm{CDCl}_{3}, 220 \mathrm{MHz}, \delta \mathrm{ppm}\right.$ from TMS) allowed the attribution of all protons: $2.78, \mathrm{~s}, 3 \mathrm{H}$, $\left(\mathrm{CH}_{3}\right) ; 3.94, \mathrm{~s}, 3 \mathrm{H},\left(\mathrm{OCH}_{3}\right) ; 6.74, \mathrm{~d}, J=2.5 \mathrm{~Hz}$, $1 \mathrm{H}, \mathrm{H}-\mathrm{C}-7 ; 7.32, \mathrm{~d}, J=2.5 \mathrm{~Hz}, 1 \mathrm{H}, \mathrm{H}-\mathrm{C}-5 ; 7.86$,

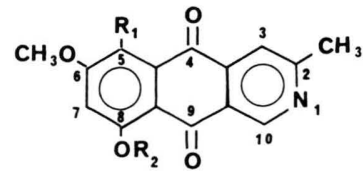

$$
\begin{array}{ll}
1 R_{1}=\mathrm{OH} & \mathrm{R}_{2}=\mathrm{H} \\
2 \mathrm{R}_{1}=\mathrm{R}_{2}=\mathrm{H} \\
3 \mathrm{R}_{1}=\mathrm{H} & \mathrm{R}_{2}=\mathrm{CH}_{3} \mathrm{CO}
\end{array}
$$<smiles>COC1=CC(=O)c2c(O)c3c(c(O)c2C1=O)C=C(C)OC3O</smiles>

4<smiles>COc1cc(O)c2c(c1)C(=O)C1=C(C2=O)C(O)OC(C)=C1</smiles>

5

Figure. 1: bostrycoidin; 2: 5-deoxybostrycoidin; 3: 5-deoxybostrycoidin acetate; 4: anhydrofusarubin lactol; 5: 5-deoxyanhydrofusarubin lactol (still hypothetical). 
$\mathrm{s}, 1 \mathrm{H}, \mathrm{H}-\mathrm{C}-3 ; 9.40, \mathrm{~s}, 1 \mathrm{H}, \mathrm{H}-\mathrm{C}-10 ; 12.76, \mathrm{~s}, 1 \mathrm{H}$, $\mathrm{OH}$ at $\mathrm{C}-8$. The relative position of the aromatic protons in the cycle $\mathrm{A}$ of $\mathbf{2}$ was further established by irradiation at $7.32 \mathrm{ppm}(\mathrm{H}-\mathrm{C}-5)$, resulting in the decoupling (and enhancement) of the signal at 6.74 ( $\mathrm{H}-\mathrm{C}-7$, meta-coupling). The position of all signals and in particular for $\mathrm{H}-\mathrm{C}-3$ and 10 was further corroborated by direct comparison with the ${ }^{1} \mathrm{H}$ NMR spectrum of bostrycoidin $1 .{ }^{13} \mathrm{C}$ NMR $\left(\mathrm{CDCl}_{3}\right): 165.6$ (C-2), 118.5 (C-3), 134.6 (C-3 a), 186 (C-4), 138.7 (C-4 a), 107.4 (C-5), 165.9 (C-6), 108.1 (C-7), 166.54 (C-8), 110.5 (C-8a), 182 (C-9), 124 (C-9a), $149.1(\mathrm{C}-10), 25.3\left(\mathrm{CH}_{3}\right), 56.1\left(\mathrm{OCH}_{3}\right)$. Acetylation of $2\left(\mathrm{Ac}_{2} \mathrm{O} / \mathrm{Py} 20 \mathrm{~h}, \quad 20{ }^{\circ} \mathrm{C}, \quad \mathrm{SiO}_{2} \quad \mathrm{TLC}\right.$ in $\mathrm{CH}_{2} \mathrm{Cl}_{2}-\mathrm{MeOH}$ 99:1, Rf 0.55) gave a yellow monoacetate 3, mp. $193-195{ }^{\circ} \mathrm{C}$, MS $m / z 311, \mathrm{M}^{+}, 269$, M-42 $(100 \%)$. The ${ }^{1} \mathrm{H}$ NMR spectrum of 3 was similar to that of $\mathbf{2}$ except for the aromatic protons at C-5 and $\mathrm{C}-7$ which were deshielded at 7.72 and $6.97 \mathrm{ppm}$ respectively and for the $\mathrm{OH}$ group at $\mathrm{C}-8$ which was replaced by the $\mathrm{CH}_{3} \mathrm{CO}$ signal at $2.52(\mathrm{~s}, 3 \mathrm{H})$.

Previous work was done with the 169 red mutant of $N$. haematococca grown in a medium containing ten times less asparagine $(0.95 \mathrm{~g} / \mathrm{l})$ than in the present study. In such conditions the pigments found were the usual dihydroxynaphthoquinones (fusarubin, hydroxynorjavanicin, bostrycoidin and others) [1-5] and the dihydrodihydroxynaphthoquinones (dihydrofusarubins, dihydrofusarubin-O-ethyl ether) [5-6]. No monohydroxynaphthoquinones have been isolated from cultures of red mutants. Monohydroxynaphthoquinones were obtained only when an additional chromosomal mutation was introduced into such red mutants, giving yellow double mutants [7].
The monohydroxynaphthoquinones: deoxyfusarubin, deoxyanhydrofusarubin and deoxyjavanicin replaced fusarubin, anhydrofusarubin and javanicin in cultures of these yellow mutants [8]. Till now, the simultaneous production of both monohydroxy and dihydroxynaphthoquinones was reported only for a Fusarium sp. strain grown in a malt extract-glucosepeptone medium [9]. In the present work, the use of a large amount of asparagine in the culture medium inhibits the biosynthesis of fusarubin and of the other nitrogen-free dihydroxynaphthoquinones but allows the formation of bostrycoidin together with a small quantity of its monohydroxy counterpart namely, 5-deoxybostrycoidin. The accumulation of bostrycoidin may be explained by the fact that asparagine furnishes ammonia so that the fusarubin aldehyde (hemiacetal 4) is immediately transformed into the heterocyclic derivative according to the previously proposed scheme [2]. The origin of deoxybostrycoidin is presently unclear. A likely hypothesis is that it arises from a hypothetical deoxyfusarubin aldehyde 5 (hemiacetal form).

The melting points were determined on a Kofler apparatus under the microscope and were corrected, the MS were obtained from an AEI MS 9 spectrometer and the NMR spectra from Bruker 220 and $400 \mathrm{MHz}$ apparatus, $\delta \mathrm{ppm}$ from TMS as internal standard.

Thanks are due to Drs. B. C. Das and C. Girard for mass spectrometric determinations, to Mrs. C. Fontaine and C. Pasquier for the ${ }^{1} \mathrm{H}$ and ${ }^{13} \mathrm{C}$ NMR spectra, to Mrs. C. Muller for elemental analysis, and to Mrs. M. Maugin (Orsay) and L. Quaino (Gif sur Yvette) for their expert technical assistance.
[1] D. Parisot, M. Devys, and M. Barbier, Phytochemistry 29, in press (1989).

[2] D. Parisot, M. Devys, and M. Barbier, J. Antibiotics 42, 1189 (1989).

[3] D. Parisot, M. Devys, and M. Barbier, Phytochemistry $27,3002(1988)$.

[4] D. Parisot, M. Devys, and M. Barbier, Microbios Letters 36, 129 (1987).

[5] D. Parisot, M. Devys, J. P. Férézou, and M. Barbier, Phytochemistry 22, 1301 (1983).
[6] M. Barbier, M. Devys, and D. Parisot, Canad. J. Chem. 66, 2803 (1988).

[7] D. Parisot, M. Maugin, and C. Gerlinger, J. Gen. Microbiol. 130, 443 (1984).

[8] D. Parisot, M. Devys, and M. Barbier, Phytochemistry 24, 1977 (1985).

[9] Y. Kimura, A. Shimado, H. Nakajima, and T. Hamasaki, Agric. Biol. Chem. 52 (5), 1253 (1988). 